\title{
Can Descartes Be Called a Perfect Dualist?
}

\author{
Shanjendu Nath \\ Associate Professor, Department of Philosophy, Rabindrasadan Girls' College, Karimganj, Assam, India.
}

\begin{abstract}
Dualism occupies an important place in the history of philosophy. In modern philosophy Descartes is called a most significant dualist philosopher as he believes the existence of two entities - mind and matter. According to him, a human being is some kind of union of two distinct things: a soul or mind and a body. He believes that body is a part of mechanical nature whereas mind is a pure thinking substance and it is spiritual in nature. These two substances have antagonistic characteristics but there is interaction with each other. His concept of mind and body is derived from his theory of substance. He believes the reality of three substances, viz., mind, body and God. Out of these three substances mind and body are called by him as dependent substances and God is the only independent substance. I think this concept of three substances vitiate his theory of dualism. Moreover, he believes the reality of many souls which also contradicts his theory of dualism. Thus in this paper I will try to delineate the ground for which he is claimed to be a dualist and also try to show grounds for which this claim is not justified. And finally, I will try to show that he is not a perfect dualist. His philosophy can correctly be called a blend of dualism, trialism and pluralism.
\end{abstract}

Key Words: Mind, Matter, Substance, Dualism, Trialism, Pluralism.

Submitted Date 17 June 2013

Accepted Date: 22 June 2013

\section{Introduction}

It is needless to mention that Descartes, a Frenchman, has brought a revolutionary change in the history of philosophy on the concept of mind and its relation to body. Prior to his appearance in the domain of philosophy, there was no clear and distinct conception about mind and he is the philosopher who has naturally aroused a new interest on this problem. This evaluation of Descartes is not an exaggeration but natural and obvious, and there are ample support in favour of this evaluation. Although we find discussions on mind from the writings of primitive man and subsequent philosophers prior to Descartes, no one has taken the problem seriously and that is why no one has given a concrete analysis on this problem. This is very clearly mentioned by T. E. Shanmugam. In his preface to the "The Concept of Mind" he writes,

"Till the advent of Descartes in the sixteenth century, the concept of mind was rather in a nebulous state in the philosophies of the west."1

It is an undeniable fact that in the seventeenth century philosophy Descartes was most impressive philosopher. He is called the most systematic dualist philosopher in modern philosophy. He really possessed an extra-ordinary power. In estimating Descartes' philosophy Anthony Kenny writes,

'His main ideas can be so concisely expressed that they could be written on the book of a postcard; and yet they were so profoundly revolutionary that they altered the course of philosophy for centuries.'

By these lines he meant that if anybody tries to synthesize the main ideas of Descartes he does not need more than two sentences and which can be consolidated on a post card. These are -

1. Man is a thinking mind, and

2. Matter is extension in motion.

\section{Dualism and its different Forms}

But before going to discuss the question whether Descartes is a dualist or not let me clarify what does the term dualism mean? Subsequently I will discuss the ground for which he is called a dualist philosopher.

Dualism is understood as a philosophical concept which holds the existence of two worlds, viz., physical world and psychical world. Mind-body dualism claims that neither the mind nor matter can be reduced to each other in any way, and thus is opposed to materialism in general, and reductive materialism in particular. Dualism is of different types, such as, substance dualism, property dualism and predicate dualism.

${ }^{1}$ T. E. Shanmugam: The Concept of Mind, $p-$ VII

${ }^{2}$ Anthony, Kenny: The Metaphysics of Mind, p-1 
According to substance dualism, both mind and body are two different kinds of substances and these are fundamentally distinct from each other. This form of dualism is advocated by Descartes which I shall discuss afterwards.

Property dualism, on the other hand, does not believe the existence of two kinds of substances in the world rather it believes the reality of two kinds properties such as, physical properties and mental properties. These two kinds of properties are different in nature and this difference is ontological. According to this theory, most of the properties, such as, having an electrical charge, or having a certain mass, are physical properties. But feeling a pain, or thinking about something are mental properties among others. This theory further believes that consciousness cannot be reduced to neurobiology and physics. Moreover, according to this theory, mental properties emerge as soon as matter is organized in the appropriate way. This theory does not postulate any separate existence of mental substance but holds that physical bodies, particularly brain of human beings possesses both physical and mental properties. Property dualism is designated by Searle as 'a weaker version of dualism.'

Property dualism is also of different types, such as, Non-reductive physicalism and epiphenomenalism. Non-reductive physicalism believes that all mental states can be causally reduced to physical states. There are different arguments in favour of this view of which one is given by Donald Davidson and others and another is given by John Searle. Davidson holds that mental events and physical events are identical and the law that governed this causal relationship is very strict. His argument is known as 'anomalous monism.'

John Searle is an advocate of distinctive form of physicalism known as biological naturalism. He says that mental states cannot be reduced ontologically to physical states but causally they are reducible.

Epiphenomenalism asserts that matter gives rise to mental states, such as, sensations, volitions etc. but these mental states cannot cause any physical events. All mental activities are nothing but by-product of bodily activities.

Predicate dualism holds the view that both mind and body have their respective properties but none can be reduced to another.

One thing I like to clear is that the purpose of my paper is not to discuss the different forms of dualism elaborately but to concentrate my discussion only on Descartes' substance dualism.

\section{Descartes as a Dualist}

Descartes is a dualist in the sense that he believes the reality of two worlds - the world of matter and the world of mind. According to him, all the tangible contents of the universe including matter, energy and human bodies belong to the first and mental events and states belong to the second. The first kind of world is publicly observable while the second is not. The second is wholly private. These two worlds are antagonistic to each other. But in spite of their antagonism there is interaction between these two worlds in a mysterious manner. This interaction also transcends the normal rules of causality and evidence.

Descartes derives the concept of mind and body from his theory of substance and there by his dualism is known as substance dualism. By 'substance' he means such thing which exists by itself and which requires nothing for its existence. In his own language he defines substance thus -

"Everything in which there resides immediately, as in a subject, or by means of which there exists anything that we perceive, i.e., any property, quality or attribute, of which we have a real idea, is called a substance, neither do we have any other idea of substance itself, precisely taken, than that it is a thing in which this something that we perceive or which is present objectively in some of our ideas, exists formally or eminently. For by means of our natural light we know that a real attitude cannot be an attribute of nothing."

From the above definition of substance it appears that if someone takes it in literal sense then it applies only to God. Because truly speaking, nothing in the world can exist by itself but God. He is alone selfsustaining and all other created things and beings are sustained by Him. This conception of substance leads Descartes to the camp of monist like Spinoza. But Descartes did not take this definition in that light. Rather unlike Spinoza and like the scholastics he uses this definition of substance in different ways. He applies the concept substance in two different senses - primary and secondary. Primarily he applies the word to God. But secondarily and analogically he applies the word to creatures; although the scholastic philosophers apply the word primarily to creatures and secondarily to God. It is because of Descartes' intention to proceed from cause to effect and not conversely. Another reason for such procedure is that he was by no means a pantheist. It is perhaps due to these couple reasons that Descartes primarily emphasized on God as substance and then on creatures.

Thus after giving a clear picture about the conception of substance Descartes divides it into three heads. These are - God, mind and body. He not only divides substance into three but also gives us a very lucid explanation of them. He says that mind is that type of substance in which there remains nothing but thought.

${ }^{3}$ Quoted from Haldane and Ross: The Philosophical Works of Descartes, Vol.II, p-53. 
By 'body' he means that it is the subject of extension. Thus extended body occupies space. But when he defines God, he gives us a very different conception of it. He says that God is supremely perfect and there is nothing involving defect in it which can limit its perfection.

From the above analysis it becomes clear that Descartes' three substances are not having equal status. These three substances are divided into two groups - dependent substances and independent. Mind and body belong to the first group while God belong to the second. He sometimes calls mind and body as relative substances because mind and body cannot exist by themselves. These are created by God and as such they are dependent on God for their existence. But God is not created by anybody else and He is not dependent on anything else for its existence. He is absolutely independent and so called 'Causa sui'.

From this standpoint Descartes says that the term 'substance' is properly applicable only to God and mind and body are not substances in the true sense of the term. But this also does not mean that Descartes altogether denies calling mind and body as substances. He only says that these are not substances as God is, namely, as self-existent. They are substances on the ground that they did not exist before God's creation. Thus before their existence they did not possess any relation with God. Again, after creation they exist outside Him.

\section{Characteristics of Mind and Body in Descartes' Dualism}

Thus after giving a clear cut definition and explanation of substance Descartes delineates the characteristics of both mind and body. He says that both mind and body are substances having antagonistic characteristics and found nothing in common between them. The features which are present in one are never found in another. In qualifying body or matter he identifies it with extension and says that it is very much passive in character and is subject to mechanical laws. It has no power of spontaneous activity like thinking, feeling or willing. Just opposite to this extended body there exists a non-extended substance called self who is the owner of all the activities like affirmation, denials, feeling, thinking, willing, doubting, understanding, refusing, imagining etc. He says that thinking is the essence of mind and so there is nothing called mind over and above a thinking substance. In distinguishing self from bodies he says that it is indivisible and unextended and conscious substance so it always thinks. And opposite to this thinking substance, body is the extended substance which is essentially divisible. Thus he says that it is quite absurd to think of an unconscious self and an unextended body.

Being a dualist Descartes holds that mind is a thing or entity which is the subject of consciousness so it is quite separate and distinct from the body. In contrast to mind, he says that, body is that which does not possess consciousness but possesses shape, size and so it occupies space. Thus he says that both mind and body have independent existence and no one can be equated with the other in respect of their attributes.

"Everything that can think is mind or is called mind, but since mind and body are really distinct, no body is a mind; hence no body can think."

Descartes repeatedly asserts that mind being a thinking substance is entirely different from body in all its nature. The defining characteristics or essence of mind is its consciousness, i.e., thought, feelings, perceptions, memories, emotions, desires etc. As opposite to body, it has no shape or size and so no spatial in character, i.e., it has no location at all.

Consistent with his view that both mind and body are separate and distinct entities Descartes further holds that they can exist independent of each other. Such a view of Descartes is correct to some extent. Because in our practical life we find that some bodies e.g., stones and lakes have existent without mind. Again, he cognizes all other animals except man as simply bodies having no minds. Similarly, he holds the view that a mind can exist even when a human body perishes in death. Since he believes that mind is immortal and so it continues to exist as disembodied entity.

From the above assertion it appears that Descartes is convinced and so he very clearly shows the existence of two substances, namely, mind and matter as separate and independent entities and says that both of them can be conceived independently as extended substance and thinking substance.

When Descartes was asked by his critics as to how does he prove that his body is distinct from his body? He replies that he has a clear and distinct idea of himself that he is a thinking being which is not extended and at the same time he also understands that he has a clear and distinct idea of his body which is not a thinking thing but extended. From this clear and distinct idea of himself as both thinking thing and extended thing he concludes with certainty that he, that is his mind, is really distinct from his body and can exist without it.

Descartes very beautifully describes the functions of mind in which he says that mind is that which thinks and performs other functions like perception, emotion, memory etc. and in doing so it sometimes leads to error. Thus he finds out the cause of such error. In his view God is free from all kinds of errors because He is the only perfect and Supreme Being. What He does is always right. It is man who is always responsible for

${ }^{4}$ R.M. Eaton (ed.) Descartes' Selection, p-178. 
errors. This view of Descartes leads to another kind of dualism, within his dualism of mind and body, viz., intellect and will. The cause of error, according to him, is unrestrained will. When the will affirms the ideas which are not clear and distinct to the intellect, errors arise. Thus on this ground he compares man with God from two different ways. He says that in one way man is like God and in another way he is less than God.

"The intellect is limited in its perception of truths; in this respect man is less than God. But the will is unlimited, it is wholly free; in this respect man is like God."

This similarity and inferiority of man with God, he makes on the basis of having will and intellect. He believes that both man and God possess unlimited will although unrestrained human will leads to error. But he is determined on the issue that although both human being and God possess intellect, the intellect of the former is limited where as the latter possesses an unlimited intellect. Thus in respect of will man is like God but in respect of intellect man is less than God.

Dualism has different advantages and drawbacks that have been highlighted by different thinkers. But I should not go on that way as my purpose in this article is to prove that Descartes is not a perfect dualist.

\section{Trialism and Pluralism in Descartes' Philosophy}

Thus from the ground offered by Descartes it appears that he is a dualist philosopher out and out as he divides the universe into two hemispheres - spirit and matter. But in thorough examination one could find that he is not really so as it apparently appears and claims to be. It will not be exaggerated if he is called a trialist philosopher. Because in his philosophy he very firmly tells us that there exist three substances, viz., Mind, Body and God. Of these three, the mind and body are called by him as created substances as because they are created and sustained by God and so these are not absolute but relative and dependent substances. They depend on God for their existence. But God is the absolute substance who does not require anything else for His existence. He is also not created by any superior entity other than Himself because $\mathrm{He}$ is the most perfect Being. His concurrence is urgently necessary for the existence of mind and mater. Descartes further opines that like all other bodies human bodies are machines. The only difference between them is that the formers are made and fashioned by man where as the latter by God. Human body can move and can perform different actions only because it is created by God and He allowed them to do so. Thus in Cartesian philosophy the whole system of the universe is described with the help of three substances and their mutual relations with one another.

In agreeing with another subsequent rationalist philosopher like Leibnitz, Descartes holds that mind is not one in number but many and each mind has a separate independent existent of its own. In this respect Descartes is called a pluralist and not a dualist or even a trialist. But there is another angle from which if Descartes is called a dualist then in the same sense Leibnitz is to be called a monist. Descartes proves himself to be a dualist only on the ground that both mind and body are equally real substances and none of them can be reduced into another. But in contrast with this view Leibnitz holds that he perceives nothing as matter. Whatever he perceives as matter is nothing but mind. Thus in this connection C. D. Broad says

"Descartes was pluralist about mind and a monist about matter, for he agreed with Leibnitz that minds are continuants and with Spinoza that bodies are occurents. ${ }^{\circ 5}$

\section{Conclusion}

So far I have explained Descartes' philosophy of dualism and I lucidly discussed the grounds for which his philosophy is called a trialistic. Now it is time to decide whether Descartes is really a perfect dualist philosopher or not. Apparently it seems that Descartes is a perfect dualist philosopher because he believes mind and body as two different elements and there is interaction between them. But on thorough analysis it is found that he is not so. Because in analyzing the mind and body he says that these are dependent on God for their existence and as such these are dependent substances. He could not explain mind body relation independently without the help of God. Thus he believes the reality of three substances - mind, body and God. In this respect his philosophy is obviously called a trialistic. Not only so, he also believes the reality of many minds and in this respect he might be called a pluralist. Thus considering all these it can be certainly said that Descartes is not a perfect dualist philosopher rather his philosophy is blended with dualism, trialism and pluralism. He is a dualist in respect of mind and body but he is trialist in respect of substance. Lastly, he is a pluralist in respect of the numbers of mind.

${ }^{5}$ C. D. Broad: The Mind and its Place in Nature, $\mathrm{p}-21$. 


\section{References}

[1] Beakley. B. and Ludlow. P, (ed), The Philosophy of Mind, Classical Problems/Contemporary Issues, New Delhi, 2007.

[2] Beck. L.J, The Method of Descartes, Oxford, 1952.

[3] Benarjee. N.V, Kant's Philosophy of Self, Arnold-Heinemann Publishers (India) p (Ltd), 1974.

[4] Block. N. (ed), Readings in the Philosophy of Psychology, Vol. 1, Cambridge, M.A Harvard University, 1980

[5] Broad. C.D, The Mind and Its Place in Nature, London, 1962.

[6] Bunge. Mario, Matter and Mind, A Philosophical Inquiry, Boston Studies in the Philosophy of Science , London, New York, 2010.

[7] Castle. A, The Self in Philosophy, London, 1965.

[8] Churchland. Paul, Matter and Consciousness, Revised Edition. MIT Press, 1984.

[9] Cunningham. G.W, The Problems of Philosophy, Calcutta, 1956.

[10] Doney. W. (ed.), A Collection of Critical Essays - Descartes, Macmillan, London, 1970.

[11] Eaton. R.M. (ed.), Descartes' Selection, New York, 1927.

[12] Gibson. A. B, The Philosophy of Descartes, London, 1932.

[13] Haldane Elizabeth. S and Ross. G.R.T. (Trans.), The Philosophical Works of Descartes, Vol. I and II, Cambridge, 1967.

[14] Hook. S. (ed.), Dimensions of Mind, New York, 1961.

[15] Keeling. S.V, Descartes, Oxford University Press, 1968.

[16] Kenny. A, The Metaphysics of Mind, Oxford, 1992.

[17] Lewis. H.D, The Elusive Mind, London, 1969.

[18] Philosophical Review, vol. LXXI, 1962.

[19] Popper. Karl R. and Eccles John C, The Self and Its Brain, Berlin: Springer, 1977.

[20] Searle. John. R,, "Why I Am Not a Property Dualist", 1983.

[21] Searle. John. R, Mind-A Brief Introduction, Oxford,2004.

[22] Shanmugam. T.E, The Concept of Mind, Bombay, 1972.

[23] Shaffer. J.A, The Philosophy of Mind, New Delhi, 1994. 